\title{
Eroding online Violence Towards Indonesian Women During Covid-19
}

\author{
Eva Solina Gultom ${ }^{1 *}$ \\ ${ }^{1}$ English Department, Faculty of Humanities, Universitas Halu Oleo, Sulawesi Tenggara-Indonesia \\ * corresponding author: eva_josgroban@yahoo.com
}

\begin{abstract}
The coronavirus has fully motivated a number of regions in Indonesia to implement Large-Scale General Restrictions (PSBB). This policy may be the right solution. However, it also brings with it a recent dilemma embracing women. PSBB has influenced individuals to limit their physical mobility and move them to use high dependence on technology platforms including the web or social media. The intensity and repetition of social media use leads to online aggression compared to the case of women. The Jakarta Women's Legal Aid Institute noted that there were 30 cases of online violence against women in Indonesia in March and April 2020. Unfortunately, this number continues to increase from year to year. Many forms of online sex-based violence exist and most of them aim to intimidate, humiliate, and dominate women. Some of them are online sexual harassment, fear of sharing personal content with exploitation themes, dating violence, and online extortion. Surprisingly, not all women in Indonesia understand and report these forms of violence to the National Commission for the Protection of Women or related agencies due to the lack of information and socialization from local governments during the pandemic. As a result, this issue marks a long list of solutions involving governments and the private sector to make online violence worse. This paper will explicitly show the importance of eradicating online violence against women during the Coronavirus in Indonesia. Courage to speak is needed. Community support to exercise their right to vote is very important to voice positive things and stop violence against women.
\end{abstract}

Keywords: covid-19, gender, indonesia, online violence, woman

\begin{abstract}
Abstrak-Virus corona telah mendorong sejumlah daerah di Indonesia untuk menerapkan Pembatasan Sosial Berskala Besar (PSBB). Kebijakan ini mungkin bisa menjadi solusi yang tepat. Namun, hal tersebut dapat menjadi dilema bagi perempuan. PSBB telah memengaruhi setiap individu untuk membatasi mobilitas fisik dan menggerakkan masyarakat untuk memiliki ketergantungan tinggi terhadap teknologi, seperti internet atau media sosial. Jumlah intensitas dan penggunaan media sosial yang semakin meningkatkian harinya, mengarah kepada agresi online terhadap perempuan. Lembaga Bantuan Hukum Perempuan Jakarta mencatat ada 30 kasus kekerasan online terhadap perempuan di Indonesia pada Maret dan April 2020. Sayangnya, jumlah ini terus meningkat dari tahun ke tahun. Ada banyak bentuk kekerasan berbasis seks online dan mayoritas di antaranya bertujuan untuk mengintimidasi, mempermalukan, mendominasi perempuan. Beberapa di antaranya adalah pelecehan seksual online, ketakutan untuk membagikan konten pribadi yang mengarah kepada eksploitasi, kekerasan dalam berpacaran, dan pemerasan online. Anehnya, tidak semua perempuan di Indonesia memahami dan melaporkan bentuk-bentuk kekerasan tersebut ke Komnas Perempuan atau instansi terkait karena minimnya informasi dan sosialisasi dari pemerintah daerah selama pandemi. Akibatnya, masalah ini menandai daftar panjang dan solusi terhadap buruknya kekerasan online yang melibatkan pemerintah dan sektor swasta. Tulisan ini secara eksplisit akan menunjukkan pentingnya pemberantasan kekerasan online terhadap perempuan selama virus Corona di Indonesia; dibutuhkan keberanian untuk berbicara. Dukungan masyarakat untuk menggunakan hak pilihnya sangat penting untuk menyuarakan hal-hal positif dan menghentikan kekerasan terhadap perempuan.
\end{abstract}

Kata kunci: covid-19, gender, indonesia, kekerasan online, perempuan

\section{INTRODUCTION}

Based on the latest update (20 January 2021), Indonesia has passed 14,224 crown infection cases in a day with the number of active cases reaching 143,517, or 16 percent of the reported cases. This percentage brings the total spread of infection crowns nationwide to 927,000 cases (https://covid19.go.id). Regarding this information, the central government recently decided to tighten restrictions across Java and Bali from January 11 to January 25, 2021 and expand some of the restrictions to public activities called Enforcement Restrictions on General Activities (PPKM).

Under PPKM, affected cities and districts will be asked to limit their work from office capacity to 25 percent, continue online learning, and limit capacity in religious facilities to 50 percent for two weeks. Furthermore, shopping centers will be required to close by 19:00, while restaurants will only be allowed to serve dine-in customers with a maximum capacity of 25 percent of their premises. The new policy makes dependence on the use of advanced technology increase. According to the Association of Indonesian Web Service Providers (APJII), the number of web users in Indonesia increased to 73.7 percent of the total population, equivalent to 196.7 million users. This growth of web users has unwittingly put the position of women at serious risk as part of web users. A recent study uncovered the impact of the coronavirus pandemic on sexual orientation inequality that underlies cases of violence against 
women. Several academics also noted an increase in reports of quarantine violence for women and children (van Gelder et al. 2020; John et al. 2020).

Moreover, this new habit has unwittingly added to the problem of rampant sexual violence and sexual orientation-based both ongoing and in cyberspace to date. Women as the highest victims are considered to have the potential to experience cyber harassment. Lack of online experience and appropriate skills puts women who have less access to the web at higher risk for computerized sexual harassment or cyber violence.

According to KomnasPerempuan, the majority of victims of online sexual harassment are women (71\%) which are dominated by students and workers (CATAHU, 2020). During the pandemic, the presence of women in computerized technology increased for various reasons, including work, studies, social interaction, entertainment, etc. In this context, the gap in advanced sexual orientation begins to emerge and leads to other problems. The National Commission for Hostile to Violence Against Women (KomnasPerempuan) reported that there were 659 cases of online sexual violence that occurred from January to October 2020. This number was actually exacerbated by the situation of the development of Coronavirus cases which was increasingly prevalent in Indonesia. Indonesia.

It should be noted that online sexual violence is a serious problem that can happen to anyone and has a tremendous impact on its victims such as mental health disorders, feelings of depression, and injury, fear of socializing, feelings of hopelessness, and suicide. When the victim experiences these impacts, it will reduce the victim's productivity. Surprisingly, not all women understand and report these forms of violence to the National Commission for the Protection of Women or related agencies due to the lack of information and socialization from local governments during the pandemic. Therefore, there are several strategies needed to address the increasing severity of online violence in Indonesia.

\section{METHOD}

The writing method used by the author is in the form of a description of textual analysis. In general, the author collects various data related to the existing problems and then analyzes the content of the discourse with the issues to be discussed. The data in this study were collected by requiring tools such as documents and literature related to Covid-19 and the rise of sexual violence in Indonesia starting from March until October 2020. For data analysis, the author uses textual analysis techniques, namely data collection, discussion, and conclusion.

\section{RESULTS}

\section{Literacy Digital towards Social Media and Online Apps}

Sexual violence is action either in the form of words or non-verbal behavior by someone to control another person to make her/him engage in unwanted sexual activity. The indicators of sexual violence involve coercion, sexual activities, and sexual satisfaction that is only felt by one party. Sexual violence is a type of violence that can occur in both public and private spaces and refers to derivative sexual behavior or deviant relationship, harming the victim and destroying the peace in society.

Based on the National Commission on Women's Protection, there is an increasing number of sexual violence cases with 542 cases of the private sphere and 226 cases of sexual violence in the community domain from January to May 2020. This number, unfortunately, went up and touched 659 cases in December 2020 (KomnasPerempuan, 2020). 

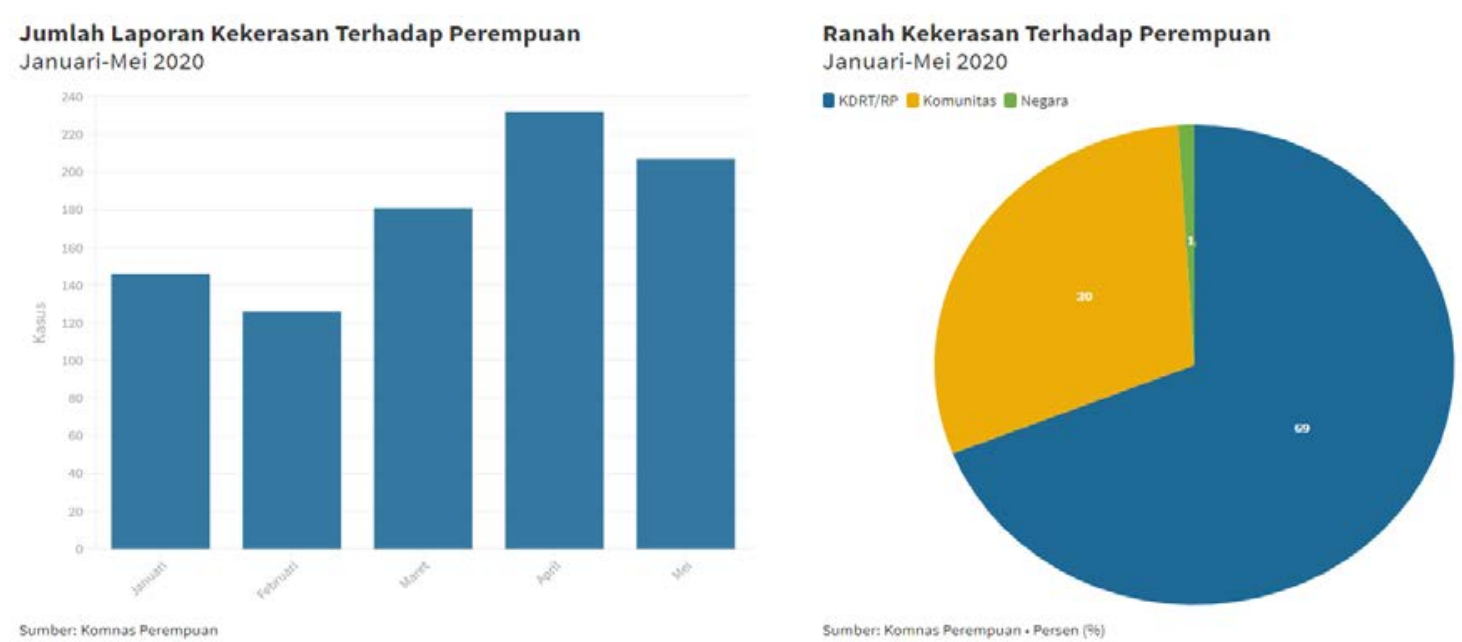

Picture 1. The report of sexual violence towards women on january - may 2020. Source: the National Commission on Women's Protection (2020)

The most reported cases of sexual violence are Online Gender-Based Violence (KGBO) which both committed by known and unknown people such as the threat of spreading, sending, or showing photos and videos with sexual nuances, exhibitionism, and sexual digital exploitations. The deliverance of these actions is in the form of sexual images or videos via direct messages to victims on Instagram, Facebook, Twitter, or any social media from the perpetrator that mostly uses a fake account.

The use of social media and online applications has unwittingly become one of the broadest domains in the current pandemic era. According to HopeHelps $\mathrm{UI}^{1}$, some KGBO cases occurred in a dating relationship and online dating apps. The exchange of private digital data is mostly misused by the perpetrators for threatening, exploiting, and extorting women. The victims tend to have concerns that digital traces are almost impossible to erase.

As a result, the victims are disturbed by fear so that they hesitate to bring the case to the law process as the culture of blaming the victims is still common in our society. Furthermore, the participation of young people in dating apps has increased during the pandemic. It takes vigilance in using dating apps considering the numbers of online sexual harassment cases including sexual abuse, rape, murder or robbery are about to rise almost every day. This shows that the digital space has become a fertile ground for predators. Technology can be perceived as not only limited as a tool or device but also as a system that shapes mindsets and patterns of social relations.

There is no technology-neutral in the perspective of feminism since it is always related to power. Therefore, the various forms and uses of technology are inseparable from the operation of the dominant power in society.

Unfortunately, the digital space that was hoped to be a space for freedom and renewal turned out to be an expansion of a culture of violence. This overview then gives rise to the assumption that the culture of violence in the digital space can be hacked. The challenge that is faced in building awareness in our network society is not only linked to digital rights but also the responsibility.

Social media literacy is urgent as it enables people to understand their all action in using the social media wisely such as tweeting, posting status, photos, or videos which may invite different reactions from another user. According to the National Commission on Women's Protection, the increase of violence against women does not only occur in the real world but also in cyberspace (CATAHU, 2020).

\footnotetext{
${ }^{1}$ It is a hotline for sexual violence in Universitas Indonesia.
} 
The harassment towards women for not appearing up to the standards or thoughts of another user (netizen) in the digital space happens so rapidly. Forms of violence like sexual messages, insults, physical threats, identity theft, and hate-speech are some of the bad effects of interactions in cyberspace that are experienced by women. In addition, there are also forms of digitization that are detrimental to women or sexual harassment victims which unwittingly experienced such as expressions of sexual abuse, platforms or applications that harm women, and content narratives that implicitly demean women.

The increasing vulnerability to digital security during this pandemic is more experienced by women. Although both men and women also have the potential to experience it, women have a higher level of sensitivity to digital security since it is related to their gender identityand the control identity when they are dealing with the cyber world. This is due to the proportion of men using the internet access is much dominant than women. There are four reasons why the level of vulnerability of women to access the internet is higher than men, such as the limited access to the internet; the lack of skills to find, create or share the content by online; the privacy strength; and the insecurity when they are exploring the digital space.

\section{The Importance of Eroding Online Violence towards Women}

The Covid-19 pandemic has had an impact on many things, including the world of work. This has made most of the industrial sectors change the work situation and work systems that are usually done face-to-face in the office are replaced remotely with the help of digital communication technology. Unfortunately, the change in the work system was not accompanied by a sexual harassment prevention instrument. This situation has brought out and increased the risk and patterns of sexual harassment practices through digital technology for workers.

From an online survey that took place April 6 to April 19, 2020, with 315 respondents working from home, it was revealed that 86 respondents of whom were victims of sexual harassment during Work from Home (WFH), 68 respondents claimed to have witnessed sexual harassment, and 30 respondents had been victims and witnesses of sexual harassment (SafeNet, 2020) ${ }^{2}$. According to a survey conducted by the Never Okay Project ${ }^{3}$, there are 85 companies that do not have a work safety instrument in the form of an anti-sexual harassment policy. From the survey findings, the majority of victims of sexual harassment during Work from Home (WFH) did not report to the company due to several factors. First, $94 \%$ of victims did not believe that the company would stand firmly on them and protect them. Moreover, $38 \%$ of victims thought that the company would not act and make an effort to fight for justice for them.

Second, the majority of victims are concerned that reporting this case to the company or any related institution, it will impact their careers. Third, victims are worried that no one will believe and support them so they are afraid to experience victim-blaming.

The survey indicated that all gender identities can be victims of sexual harassment while they are working from home. The survey results also show that work relations within the company affect someone's vulnerability to sexual harassment. The majority of the victims were in a working relationship such as contract workers, apprentices, and staff. Meanwhile, there were no entrepreneurs who had been victims. The survey also found that sexual harassment experienced by workers occurred between digital platforms that are used for working in a high frequency. $78 \%$ of victims have been harassed on 2 to 7 communication technologies at once within 1 month during working from home (WFH). The results of this survey were unilaterally supported by SafeNet. They revealed that messaging applications, such as WhatsApp, Line, Telegram, and others. They were the most frequently used channels

\footnotetext{
${ }^{2}$ SAFEnet is Southeast Asia Freedom of Expression Network. Their mission is to fight for digital rights in Southeast Asia

${ }^{3}$ Never Okay Project is the first mission-drive initiatives in Indonesia to support community and institutions to create workplace without sexual harassment.
} 
for perpetrators to commit sexual harassment $(40 \%)$, followed by social media applications (19\%), video conferencing applications (16\%), internal company applications (10\%), email (7\%), telephone (5\%), and Short Message Services (3\%).In the world of work, digital and online communication technologies, such as video conferencing and messaging applications, are generally used for group work or for many people at once. If this technology becomes the place where the most sexual harassment is experienced by workers, it means that the culture of acknowledgment or normalization of harassment is still very strong and it can be done in group communication, which includes their own colleagues.

This survey also found several forms of sexual harassment experienced by victims. They are transferred in the form of sexual jokes or jokes or sent multimedia content, such as photos, videos, audio, text messages, or stickers that have sexual nuances in a non-consensual manner. Plus, all of these events can take place across multiple platforms. Surprisingly, there are $78 \%$ of victims had experienced sexual harassment on more than two platforms. If this action insisted to continue, there will be impacts that happen to cultural sexism and online misogynism so that it perpetuates gender inequality in the offline realm. Online harassment and violence gender-based have disadvantaged women by limiting their ability to obtain the same opportunities as men, such as work, promotion, and self-expression. In addition to the impact on individuals, the main consequence of cyber violence online is the creation of society where women no longer feel secure online and offline.According to the Internet Governance Forum, there are impacts on this action as following:

1. Psychological Loss

Most of the victims experience feelings of anxiety, fear, and depression which affect their roles, behaviors, and attitude towards the environment (Beran and Li, 2005). Furthermore, there is also a certain point where some victims tend to harm their selves and suicide.

2. Being solitude

The victims choose to withdraw themselves from the public, including their family and friends. This is mainly applied to women whose personal photos and videos were publicly distributed without their consent. They feel humiliated and abused by the public. Moreover, they also feel insecure about their future and being distrustful to use any digital technology. They decided to cut off access to worldwide information, service electronics, and any social communication.

3. Economic Loss

Cyber violence has also impacted economic loss. Since being in solitude has become the best option, the victims tend to limit their space in the work field. Surprisingly, most of the victims chose not to work for a certain period to recover their psychological situation.

\section{CONCLUSION}

The protection of privacy in cyberspace is the main key and self-protection from any virtual violence or crime in the world. Users of virtual technology should limit their access to personal information from the public. In the online realm, protection of privacy involves sensitive or personal data from the access of the public both online and offline.

\section{REFERENCES}

Barak, Azy. 2005. "Sexual Harassment on the Internet." Social Science Computer Review 23(1):77-92. https://doi.org/10.1177/0894439304271540

Connell, R. W. 1995. Masculinities. Berkeley: University of California Press.

Crimmins, Danielle M., and Kathryn C. Seigfried-Spellar. 2014. "Peer Attachment, Sexual Experiences, and Risky Online Behaviors as Predictors of Sexting Behaviors among Undergraduate Students." Computers in Human Behavior 32:268-75. https://doi.org/10.1016/j.chb.2013.12.012

Cuklanz, Lisa M. 2000. Rape on Prime Time: Television, Masculinity, and Sexual Violence. Philadelphia: University of Pennsylvania Press.

DeKeseredy, W. S., and M. Corsianos. 2016. Violence against Women in Pornography. New 
York: Routledge.

DeKeseredy, Walter S., and Martin D. Schwartz. 2016. "Thinking Sociologically About ImageBased Sexual Abuse." Sexualization, Media, \& Society 2(4):1-8. https://doi.org/10.1177/2374623816684692

Van Gelder, N., A. Peterman, A. Potts, M. O'Donnell, K. Thompson, N. Shah, and S. OerteltPrigione. 2020. "COVID-19: Reducing The Risk of Infection Might Increase the Risk of Intimate Partner Violence." 21:1-2. https://doi.org/10.1016/j.eclinm.2020.100348

Gundersen, Kristin K., and Kristen L. Zaleski. 2020. "Posting the Story of Your Sexual Assault Online: A Phenomenological Study of the Aftermath." Feminist Media Studies 1-13. https://doi.org/10.1080/14680777.2019.1706605

John, Neetu, Sara E. Casey, Giselle Carino, and Terry McGovern. 2020. "Lessons Never Learned: Crisis and Gender-based Violence." Developing World Bioethics 20(2):65-68. https://doi.org/10.1111/dewb.12261

Kelly, Liz. 1988. Surviving Sexual Violence. Cambridge: Polity Press.

Zhong, Linda R., Mark R. Kebbell, and Julianne L. Webster. 2020. "An Exploratory Study of Technology-Facilitated Sexual Violence in Online Romantic Interactions: Can the Internet's Toxic Disinhibition Exacerbate Sexual Aggression?" Computers in Human Behavior 108:110. https://doi.org/10.1016/j.chb.2020.106314 